\title{
PARAMETERS THAT EFFECT EFFICIENCY IN HEAT INSULATION AND A SUGGESTION FOR SYSTEM DESIGN FOR HEAT INSULA- TION APPLICATIONS IN TURKEY ${ }^{1}$
}

\section{ISI YALITIMINDA VERIMI ETKILEYEN PARAMETRELER VE TÜRKIYE'DE ISI YALITIM UYGULAMALARINA YÖNELIK SISTEM TASARIMI ÖNERISI}

Filiz ŞENKAL SEZER

Uludag University, Faculty of Architecture, Department of Architecture, Bursa / Turkey

\begin{abstract}
Öz: Enerji etkin bina tasarım sürecinde enerji tasarrufu sağlamada yalıtım malzemelerinin önemi bilinen bir gerçektir. Ancak bu noktada ortaya çıkabilecek hatalar, hem bina hem de enerji tüketimi üzerinde olumsuz etki doğurmaktadır. $\mathrm{Bu}$ çalışmada öncelikle 1 sı yalıtımından optimum verimi alabilmek için dikkate alınması gereken parametreler belirlenmiştir. Bunlar; "Yalıtım Malzemesi Seçimi", "Yalıtım Kalınlığı Tespit"i, "Yalıtım Şekli" ve "Yalıtım Uygulaması"dır. Çalı̧̧manın son bölümünde Türkiye'de 1sı yalıtımının doğru bir şekilde uygulanmasına yönelik olarak bir sistem tasarımı önerisi sunulmuştur. Öneri planlama, tasarım ve uygulama olmak üzere 3 aşamadan oluşmaktadır.
\end{abstract}

Anahtar Kelimeler: Isı yalıtımı, Enerji verimliliği, Yalıtım tipi, Yalıtım Uygulaması
Abstract: The importance of heat insulation materials is known for energy efficient building design. However, mistakes regarding this result in negative results both for the building itself and for energy consumption. In this study the parameters that needs to be taken into consideration for optimum energy efficiency were defined. These are: "Selection of Insulation Materials", "Determination of Insulation Thickness", "Insulation Type", and "Insulation Application". In the last part of this study a system design suggestion is made to ensure heat insulation in Turkey is carried out correctly. The suggestion has three phases, namely planning, design, and implementation.

Key Words: Heat insulation, Energy efficiency, Insulation type, Insulation Applicatio

Doi: 10.17365/TMD.20160921731

${ }^{1}$ Corresponding Author: Filiz ŞENKAL SEZER, Uludă̆ University, Faculty of Architecture, Department of Architecture, Bursa / Turkey, filizss@gmail.com Received: 13.07.2016 Accepted:26.10.2016 Type of article (Research-Application) Conflict of Interest: None "None of Ethics Committee" 

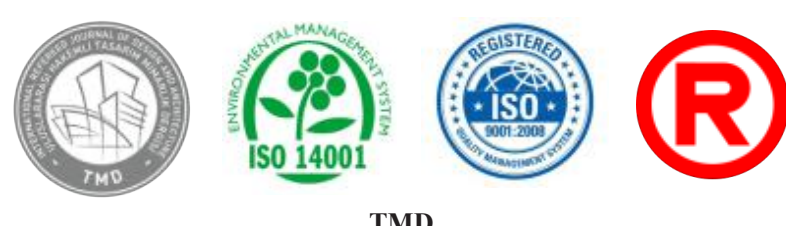

TMD

www.mtddergisi.com

ULUSLARARASI HAKEMLİ TASARIM VE MIMARLIK DERGISİ

Eylül / Ekim / Kasım / Aralık 2016 Sayı: 09 Sonbahar Kış

INTERNATIONAL REFEREED JOURNAL OF DESIGN AND ARCHITECTURE

September / October / November / December 2016 Issue 09 Autumn Winter ID:117 K:196

ISSN Print: 2148-8142 Online: 2148-4880

(ISO 9001-2008 Belge No / Document No: 12879 \& ISO 14001-2004 Belge No / Document No: 12880)

(Marka Patent No / Trademark)

(2015/04018 - 2015/GE/17595)

\section{INTRODUCTION}

The importance of insulation materials for energy conservation is known in the energy efficient building design process. Insulation materials are used to reduce heat loss and gain because of their high heat resistance. The significance of heat insulation for energy efficiency is indisputable. However any mistake related to this can present a negative impact both for the building and for energy consumption. This study first sets the parameters that effect the efficiency heat insulation and makes a suggestion for a system design to ensure that heat insulation is implemented correctly in Turkey.

\section{PARAMETERS THAT EFFECT THE EFFICIENCY OF HEAT INSULATION}

There are four parameters that have to be taken into consideration for optimum efficiency of heat insulation applications. These are "Selection of Heat Insulation Materials", "Determination of the Insulation Thickness", "Type of Insulation" and "Application of Insulation".

\section{A. SELECTION of INSULATION MATE-} RIAL: There is still a misunderstanding in Turkey about insulation materials; believing that using gas concrete, pumice concrete eliminates the need to use insulation, that there will be enough insulation if the outer layer of buildings is coated (with glass mosaic, vinyl or aluminum), and that only 3 to 5 centimeters of insulation plaster would be enough for proper insulation.
The main features of insulation materials that needs to be taken into consideration are; Coefficient of Thermal Conductivity $(\lambda \mathrm{h})$, Moisture Resistance, Water Vapor Diffusion Resistance Coefficient $(\mu)$, and general features such as Impact of the Material on Health, Resistance of the Material to Various Forces, Resistance, Indeformability, Fire Resistance, Usability, Density and Transportation. The materials that are used today are classified in Table 1 (Eurima, 2016; Berge, 2009; Kwok \& Grondzik, 2007; Wong, Eames \& Perera, 2007; Papadopoulos, 2005). Starting from 01 January 2008, the products that are defined in the Building Materials Regulation in Turkey are required to have the $\mathrm{CE}$ certificate if they are exchanged in domestic and EU markets. $\mathrm{CE}$ mark shows that the materials conform completely to the regulation and relevant terms of references. 

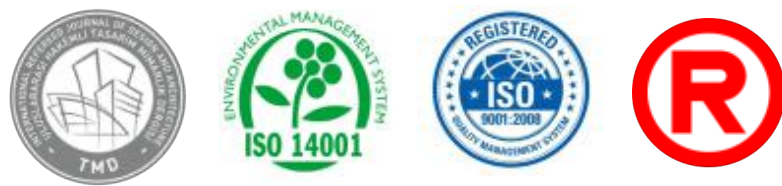

TMD

www.mtddergisi.com

ULUSLARARASI HAKEMLİ TASARIM VE MIMARLIK DERGİSI

Eylül / Ekim / Kasım / Aralık 2016 Sayı: 09 Sonbahar Kıș

INTERNATIONAL REFEREED JOURNAL OF DESIGN AND ARCHITECTURE

September / October / November / December 2016 Issue 09 Autumn Winter ID:117 K:196

ISSN Print: 2148-8142 Online: 2148-4880

(ISO 9001-2008 Belge No / Document No: 12879 \& ISO 14001-2004 Belge No / Document No: 12880) (Marka Patent No / Trademark)

(2015/04018 - 2015/GE/17595)

Table 1. Classification of Insulation Materials

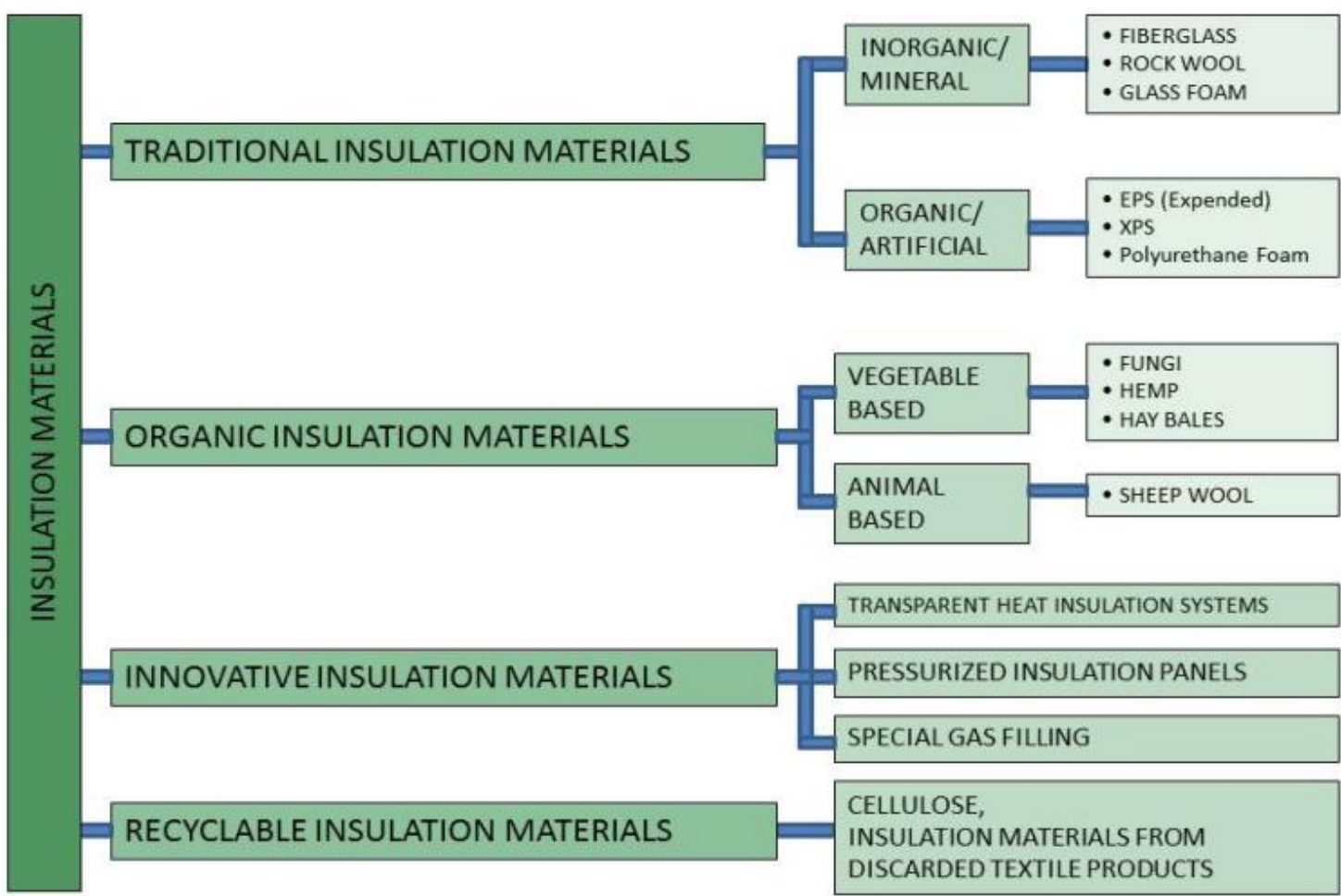

Building Materials Regulation (89/106/EEC) was published on 08.09.2002 on the Official Gazette issue 24870. The regulation was prepared by the Ministry of Public Works and Settlement and defines the basic criteria for building materials and the compatibility evaluation procedures to be used for these materials. Materials that are to be marketed have to conform to this regulation (TEVEM, 2015).

In Turkey there are four different institutions (ÇEVKAK, TEBAR, TSE, and RMI) that provide laboratory services according to TS EN ISO/IEC 17025 standard related to heat insulation materials. However, in Turkey there are no inspection mechanism related to the pro- duction and marketing of heat insulation materials. There is a supervision problem related to this issue. There is a need for regulations related to the supervision of the quality and standards of insulation materials. Additionally, there are no publications of World Health Organization on the impact of insulation materials on human health.

\section{B. DETERMINATION OF THE INSU-} LATION THICKNESS: The thickness of insulation applications is determined by calculations that aim to keep the yearly heating energy to a minimum in buildings. According to the BEP regulation of Turkey the calculation for the "Heat Insulation Project" should 


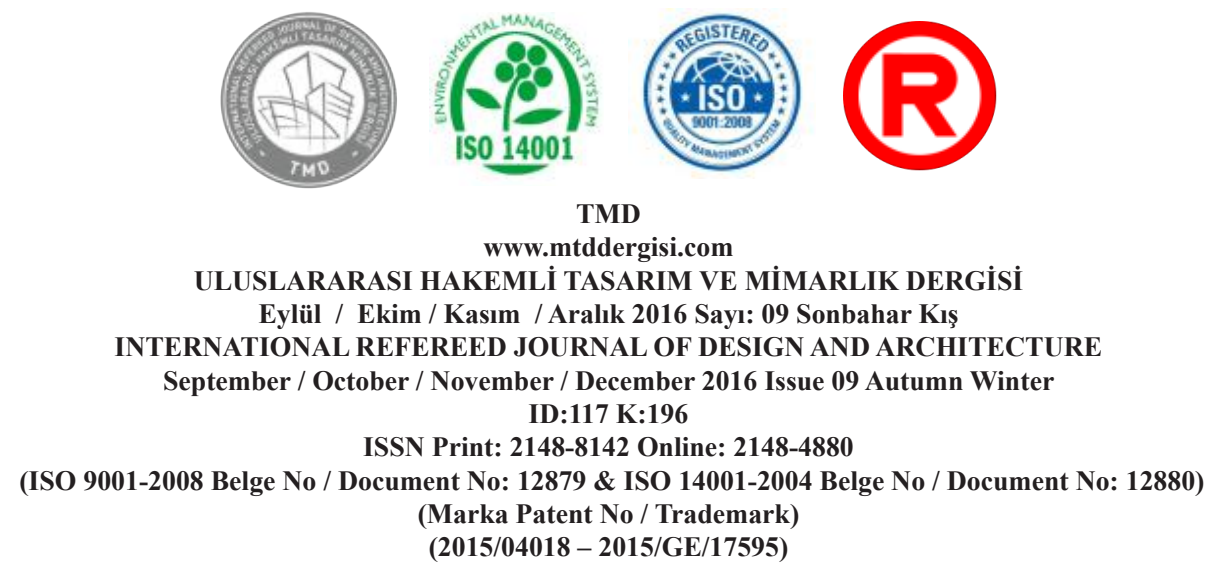

be based on the method that is defined in the TS 825 standard (Energy Efficiency Law, 2007; TS 825, 2009). In new buildings this is done during the procedures related to issuing a building license and in existing buildings this is done with refurbishment projects. The thickness of insulation both data related to climate conditions and woodwork and glass selection are important. The ratio of transparent surfaces and the type of their material are also important for the calculation of necessary heating energy. Today there is still a misbelief that insulating the façade facing north is enough and there is no need to insulate buildings in temperate regions.

C. TYPE OF INSULATION: To decide on the method of insulation on the roofs (terrace or sloped), walls, tiling, heat bridges and windows the following should be checked: if the insulation level is adequate, all heat bridges are insulated, the layer order in structural members are selected appropriately, if the condensation checks were carried out, and if necessary measures were taken against fires.

There are no regulations related to the selection of the insulation method in buildings. In new buildings we see insulation applied at the outside of buildings and between double walls and in existing buildings we often see insulation from the inside of the building because it is practical and economic. However, it should be noted that insulation from the inside will create condensation problems in time and because heat bridges will be left in the open the efficiency will be lower than the desired levels (Dilmaç et al, 2005). Therefore, insulation from the outside should be recommended (Figure 1).
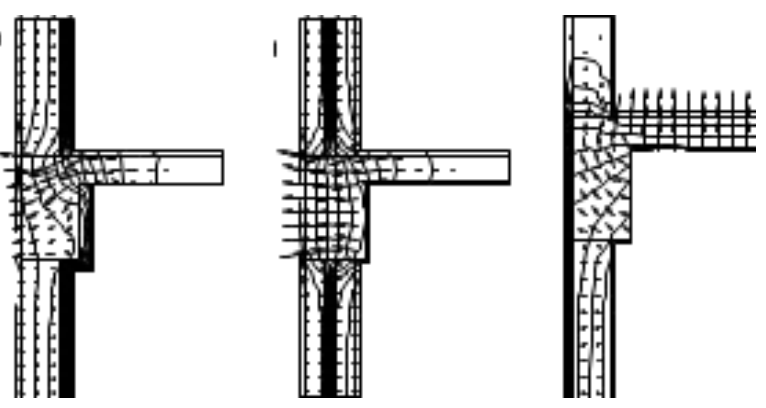

Figure 1. Heat Loss in Different Insulation Applications (Quick Field Student Edition)

D. INSULATION APPLICATION: The building that will be insulated should

definitely be examined by experts and the insulation thickness that is seen fit should be applied by qualified and experienced personnel. The only terms of reference that is in force related to insulation applications is the TS 13491 "Heat Insulation Products, EPS Application Rules for Buildings" (TS 13491, 2011). There are no other terms of references that are in force. In applications companies use their own terms of references. There is a need to fill this gap.

All the parameters that are needed to be taken into consideration in heat insulation applications are shown in Table 2. 

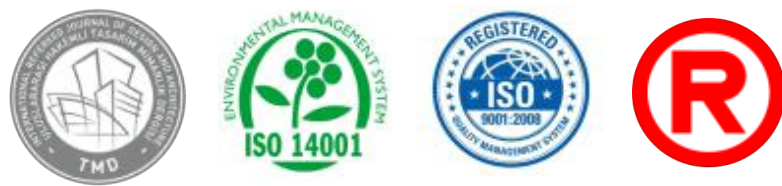

TMD

www.mtddergisi.com

ULUSLARARASI HAKEMLİ TASARIM VE MIMARLIK DERGİSI

Eylül / Ekim / Kasım / Aralık 2016 Sayı: 09 Sonbahar Kış

INTERNATIONAL REFEREED JOURNAL OF DESIGN AND ARCHITECTURE

September / October / November / December 2016 Issue 09 Autumn Winter ID:117 K:196

ISSN Print: 2148-8142 Online: 2148-4880

(ISO 9001-2008 Belge No / Document No: 12879 \& ISO 14001-2004 Belge No / Document No: 12880)

(Marka Patent No / Trademark)

(2015/04018 - 2015/GE/17595)

Table 2. Parameters That Needs to be Taken Into Consideration During Insulation Applications

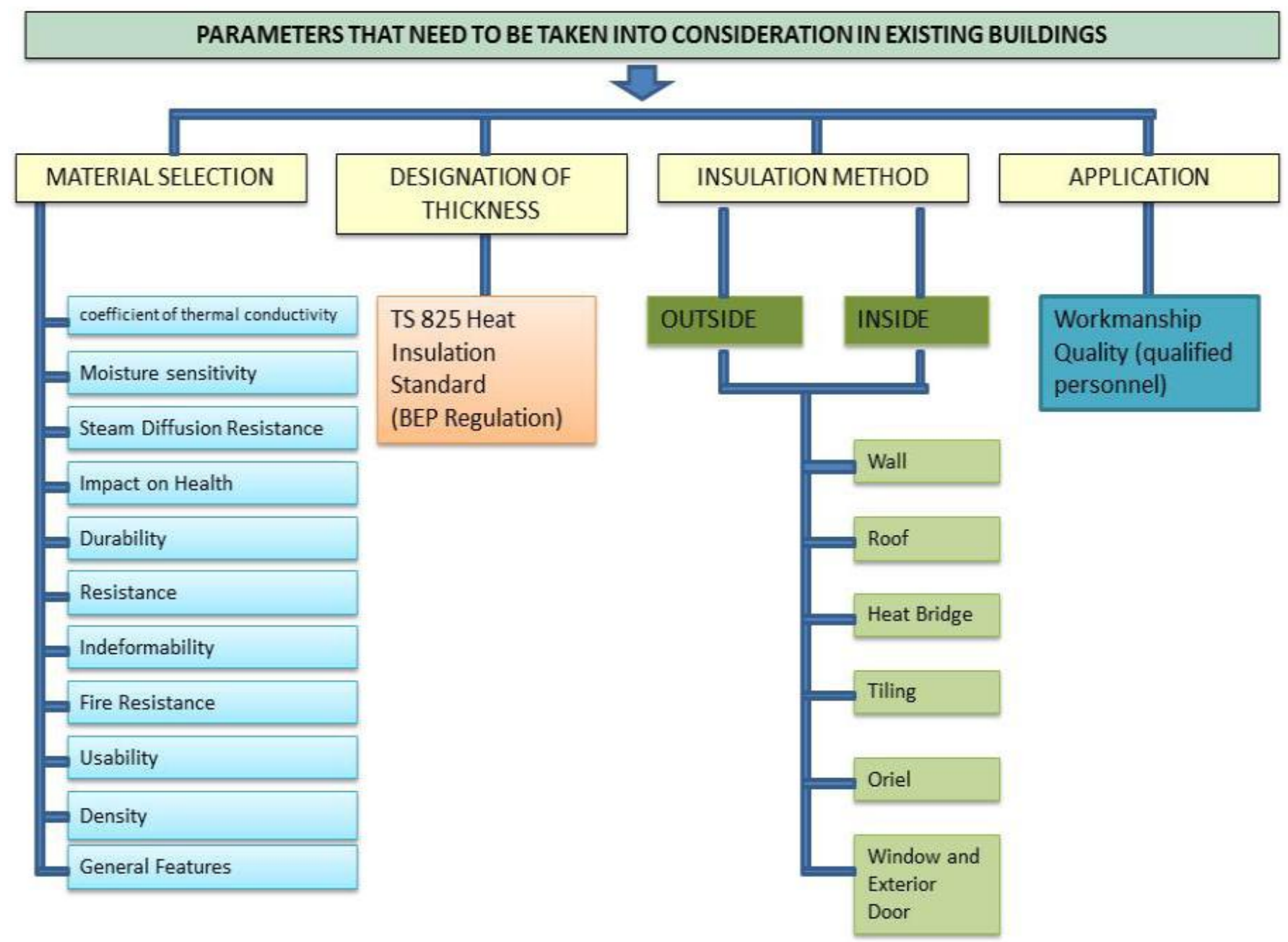

\section{SYSTEM DESIGN SUGGESTION}

In this part of the study a draft model is suggested and aims to reduce the losses of insulation applications caused by inadequate qualification and training of personnel that carry out insulation applications, the suggest- ed model can be developed further. The suggestion has three phases, namely planning, design and implementation.

The goal, scope and the training sub goals of the planning phase are shown in Table 3. 

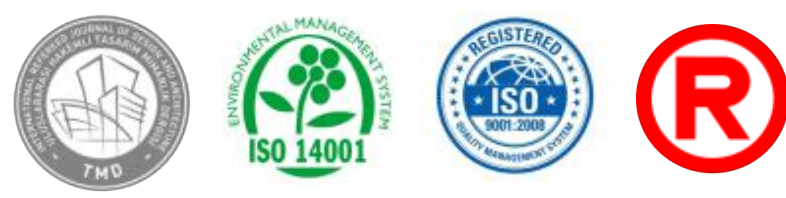

TMD

www.mtddergisi.com

ULUSLARARASI HAKEMLİ TASARIM VE MIMARLIK DERGISİ

Eylül / Ekim / Kasım / Aralık 2016 Sayı: 09 Sonbahar Kış

INTERNATIONAL REFEREED JOURNAL OF DESIGN AND ARCHITECTURE

September / October / November / December 2016 Issue 09 Autumn Winter ID:117 K:196

ISSN Print: 2148-8142 Online: 2148-4880

(ISO 9001-2008 Belge No / Document No: 12879 \& ISO 14001-2004 Belge No / Document No: 12880)

(Marka Patent No / Trademark)

(2015/04018 - 2015/GE/17595)

Table 3. Training System Design - Planning Process for Heat Insulation Implementers

TRAINING SYSTEM DESIGN FOR INSULATION MATERIAL IMPLEMENTERS

Training implementer personnel to ensure different insulation materials are applied
correctly (to achieve necessary efficiency)
be widened)

Occupational Standards Department, in the scope of the European Qualifications Framework has published on 21 March 2011 at the Official Gazette the "Heat Insulator" definition with a reference code 11UMS0132-3 as a part of the National Occupational Standards (Ministry of Energy and Natural Resources, 2016; Turkish Energy Institute, 2016). However, there is no "implementation training" except those provided by companies themselves. The design process of the model is composed of preparation of a Guide for Trainers and Im- plementers. The implementation process ends with giving the training and assessment and evaluation. Successful applicants will receive "Implementer License" (Table 4). 

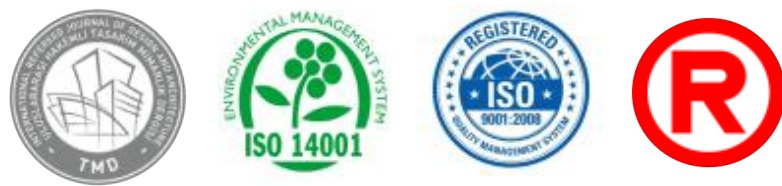

TMD

www.mtddergisi.com

ULUSLARARASI HAKEMLI TASARIM VE MIMARLIK DERGİİ

Eylül / Ekim / Kasım / Aralık 2016 Sayı: 09 Sonbahar Kıș

INTERNATIONAL REFEREED JOURNAL OF DESIGN AND ARCHITECTURE

September / October / November / December 2016 Issue 09 Autumn Winter ID:117 K:196

ISSN Print: 2148-8142 Online: 2148-4880

(ISO 9001-2008 Belge No / Document No: 12879 \& ISO 14001-2004 Belge No / Document No: 12880)

(Marka Patent No / Trademark)

$(2015 / 04018$ - 2015/GE/17595)

Table 4. Training System Design - Implementation Process for Heat Insulation Implementers
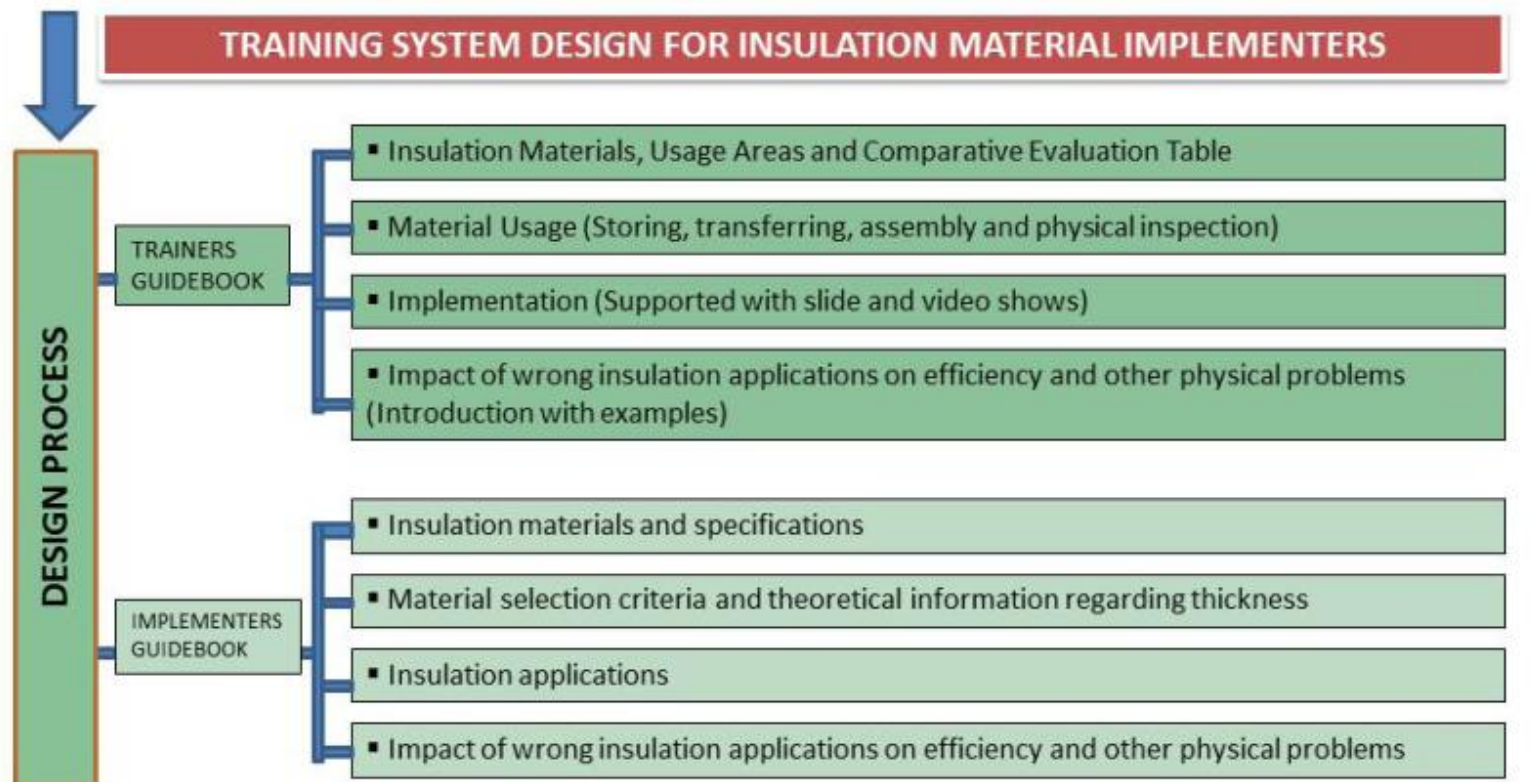

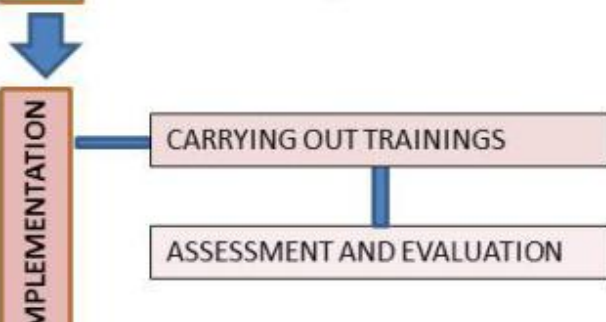

DISCUSSIONS

The Regulation of Energy Performance calculates the amount of annual energy consumption per $\mathrm{m}^{2}$ of existing and new buildings larger than $1000 \mathrm{~m}^{2}$ and related $\mathrm{CO}_{2}$ emissions. "Energy Performance Certification" system began on 01.01.2011 in Turkey. Energy Performance Certificate aims the classification of energy consumption and minimum energy needs of a building. Existing buildings larger than $1000 \mathrm{~m}^{2}$ (up to 02.05 .2017 ) and the new buildings are obliged to take the Energy
Performance Certificate. Energy Performance Certificate is an important assessment tool in terms of improving the energy efficiency of buildings whose energy class is $\mathrm{D}$ and under $\mathrm{D}$, determining the amount of greenhouse gases emitted to environment by buildings and determining the use of renewable energy sources in buildings. As a minimum, it contains information about the classification of the building's energy need and energy consumption, insulation conditions and heating and/or cooling system efficiency. It is valid 


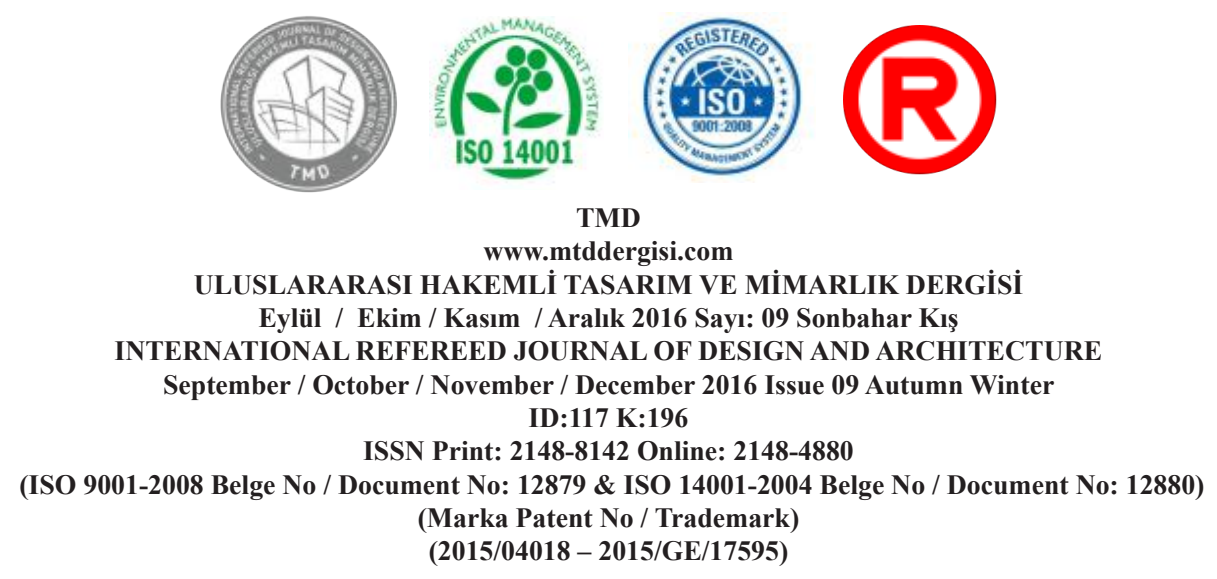

for 10 years from the date of arrangements. At the end of this time Energy Performance Certificate is reorganized in accordance with a report.

The preparation of energy performance certificate in Turkey in the scope of the regulation entitled Energy Performance in Buildings has a narrower scope compared to the systems that are used in the world. Different certificate systems need to be created for different building types that are unique to Turkey. Currently the regulations are only imperative for new buildings, which is not enough. If over consumption is not reduces the environmental impact will be hard to be minimized.

Being a country with a large uninsulated building stock, we need to develop solutions that will ensure maximum energy performance of current buildings. Private institutions and organizations need to come together for this goal and necessary regulations, laws and rules should be prepared.

Success in energy conservation will be possible with the increased awareness of the public. Therefore, as indicated in this study heat insulation and implementations need to be taken seriously and necessary standards and regulations should be put into effect. Future studies will focus on users' natural resource consumption and sharing the results with the public in order to increase public awareness on the issue.

\section{REFERENCES}

BERGE, B., (2009). The Ecology of Building Materials, ISBN: 978-1-85617-537-1, Elsevier Ltd. Burlington, USA, 23-26, 44-46

DILMAÇ, Ş., GÜNER, A., KAYGUSUZOĞ$L U, G ., C \dot{I H A N}, M . T .$, ŞENKAL SEZER, F., KARTAL, S., KALPAK, Ö., (2005). Döşemelerde Yanal Isı Kayıplarının Hesaplanması İçin Parametrelerin Belirlenmesi, Proje No: İÇTAG - 1242 (Defining Parameters to Calculate Lateral Heat Loss in Tiling, Project No: IÇTAG-1242), TÜBİTAK

ENERJI VE TABİ KAYNAKLAR BAKANLIĞI (MINISTRY OF ENERGY AND NATURAL RESOURCES). (2016). www.enerji.gov.tr, (Accessed: 19.05.2016)

ENERJI VERIMLILİĞI KANUNU (ENERGY EFFICIENCY LAW). (2007). Kabul tarihi: 18.04.2007, Kanun no: 5627, Tertip: 5, Cilt: 46

EUROPEAN INSULATION MANUFACTURIES ASSOCIATION. (2016). www.eurima.org (Accessed: 19.05.2016) 

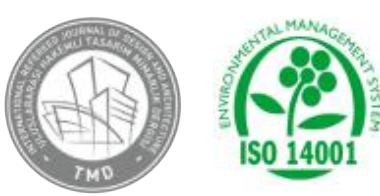

ISO 14001
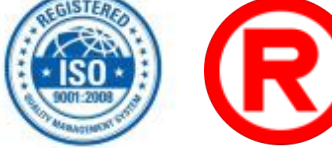

TMD

www.mtddergisi.com

ULUSLARARASI HAKEMLİ TASARIM VE MIMARLIK DERGİSI

Eylül / Ekim / Kasım / Aralık 2016 Sayı: 09 Sonbahar Kış

INTERNATIONAL REFEREED JOURNAL OF DESIGN AND ARCHITECTURE

September / October / November / December 2016 Issue 09 Autumn Winter ID:117 K:196

ISSN Print: 2148-8142 Online: 2148-4880

(ISO 9001-2008 Belge No / Document No: 12879 \& ISO 14001-2004 Belge No / Document No: 12880)

(Marka Patent No / Trademark)

$(2015 / 04018$ - 2015/GE/17595)

KWOK, A., GRONDZIK, W., (2007). The

Green Studio Handbook, ISBN-13:

978-0-7506-8022-6, Elsevier Ltd.

Burligton, USA

PAPADOPOULOS, A.M., (2005). State of the Art in Thermal Insulation Materials and Aims for Future Developments, Energy and Buildings, 77-86

TEVEM, (2015). Türkiye Enerji Verimliliği Meclisi (Turkish Energy Efficiency Council).

TS, (2011). 13491 Is1 Yalıtım Mamülleri Binalar İçin EPS Uygulama Kuralları (Heat Insulated Buildings, EPS Application Rules)

TS (2009). 825 Binalarda Is1 Yalitım Kuralları. Revize (Heat Insulation Rules for Buildings, Revised) Mecburi Standart Tebliğii, Ankara

\section{Türkiye Enerji Enstitüsü (Turkish Ener-}

gy Institute), (2016). www.enerjienstitüsü.com, (Accessed: 19.05.2016)

WONG, I.L., EAMES, P.C., PERERA R.S., (2007). A Review of Transparent Insulation Systems and The Evaluation of Payback Period For Building Applications, Solar Energy, Vol:81, 1058-1071 